Curried Cultures 
CALIFORNIA STUDIES IN FOOD AND CULTURE Darra Goldstein, Editor 


\title{
Curried Cultures
}

GLOBALIZATION, FOOD, AND SOUTH ASIA

\author{
EDITED BY
}

Krishnendu Ray and Tulasi Srinivas

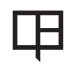

UNIVERSITY OF CALIFORNIA PRESS BERKELEY LOS ANGELES LONDON 
Elizabeth Buettner's “'Going for an Indian': South Asian Restaurants and the Limits of Multiculturalism in Britain" was first printed in slightly different form in The Journal of Modern History, 80 (4), 865-90I. It is reprinted here with permission. Jayanta Sengupta's “Nation on a Platter: The Culture and Politics of Food and Cuisine in Colonial Bengal" was first printed in slightly different form in Modern Asian Studies, 44(I), 8I-98. It is reprinted here with permission. Krishnendu Ray's "Global Flows, Local Bodies: Dreams of Pakistani Grill in Manhattan” was printed in different form (and under a different title) in Food, Culture \& Society, I4(2) 243-273.

University of California Press, one of the most distinguished university presses in the United States, enriches lives around the world by advancing scholarship in the humanities, social sciences, and natural sciences. Its activities are supported by the UC Press Foundation and by philanthropic contributions from individuals and institutions. For more information, visit www.ucpress.edu.

University of California Press

Berkeley and Los Angeles, California

University of California Press, Ltd.

London, England

(C) 2012 by The Regents of the University of California

Library of Congress Cataloging-in-Publication Data

Curried cultures : globalization, food, and South Asia / edited by Krishnendu Ray and Tulasi Srinivas.

p. $\mathrm{cm}$.

Includes bibliographical references and index.

ISBN 978-0-520-270II-4 (cloth : alk. paper)

ISBN 978-0-520-270I2-I (pbk. : alk. paper)

I. Food-Social aspects-South Asia. 2. Food habits-South Asia.

3. Cosmopolitanism-South Asia. 4. Nationalism-South Asia.

5. Globalization-Social aspects. I. Ray, Krishnendu. II. Srinivas, Tulasi.

$\mathrm{GT}_{2} 853 . \mathrm{S}_{4} \mathrm{C} 8722012$

394.I'20954-dc23

2011029711

Manufactured in the United States of America

$\begin{array}{llllllllll}\text { II } & 20 & \text { I9 } & \text { I } 8 & \text { I7 } & \text { I6 } & \text { I5 } & \text { I } 4 & \text { I3 } & \text { I2 }\end{array}$

$\begin{array}{llllllllll}\text { I0 } & 9 & 8 & 7 & 6 & 5 & 4 & 3 & 2 & \text { I }\end{array}$

In keeping with a commitment to support environmentally responsible and sustainable printing practices, UC Press has printed this book on 50-pound Enterprise, a $30 \%$ post-consumer-waste, recycled, deinked fiber that is processed chlorine-free. It is acid-free and meets all ANsI/NISO ( $\left.\mathrm{z}_{39.48}\right)$ requirements. 
To my mother Rukka Srinivas for stirring in me a fascination for all things gastronomic.

To Rudra and Babul for keeping me sane.

To Sierra Burnett Clark and Jackie Rohel for all the unacknowledged work. 
This page intentionally left blank 